\title{
Smiljana Komar
}

University of Ljubljana

Faculty of Arts, English Department

\section{Unenthusiastic Europeans or Affected English: the Impact of Intonation on the Overall Make-up of Speech}

\author{
Summary
}

Attitudes and emotions are expressed by linguistic as well as extra-linguistic features. The linguistic features comprise the lexis, the word-order and the intonation of the utterance. The purpose of this article is to examine the impact of intonation on our perception of speech. I will attempt to show that our expression, as well as our perception and understanding of attitudes and emotions are realized in accordance with the intonation patterns typical of the mother tongue. When listening to non-native speakers using our mother tongue we expect and tolerate errors in pronunciation, grammar and lexis but are quite ignorant and intolerant of non-native intonation patterns. Foreigners often sound unenthusiastic to native English ears. On the basis of the results obtained from an analysis of speech produced by 21 non-native speakers of English, including Slovenes, I will show that the reasons for such an impression of being unenthusiastic stem from different tonality and tonicity rules, as well as from the lack of the fall-rise tone and a very narrow pitch range with no or very few pitch jumps or slumps.

Key words: linguistics, prosody, contrastive analysis

\section{Medli Evropejci ali izumetničeni Angleži: vpliv intonacije na celostno podobo govora}

\section{Povzetek}

Čustva in stališča do sogovorcev oziroma do povedanega se izražajo z jezikovnimi kakor tudi nejezikovnimi sredstvi. Jezikovna sredstva sestavljajo besedišče, besedni red in stavčna intonacija. Namen tega članka je analizirati vpliv intonacije na naše dojemanje govora. Poskušala bom dokazati, da sta tako izražanje kot razumevanje govora pogojena z intonacijskimi vzorci, značilnimi za materni jezik. Kadar poslušamo nerojene govorce, ki se sporazumevajo v našem maternem jeziku, pričakujemo in $\mathrm{z}$ razumevanjem sprejemamo napake $\mathrm{v}$ izgovorjavi, slovnici in besedišču, hkrati pa težko razumemo in sprejemamo intonacijske vzorce, ki niso značilni za naš materni jezik. Tujci pogosto zvenijo dolgočasno in nezainteresirano za rojene govorce angleščine. $\mathrm{Na}$ podlagi analize angleškega govora 10 Slovencev in 11 pripadnikov drugih evropskih jezikov bom dokazala, da razlogi za takšno slušno zaznavo angleščine nerojenih govorcev tičijo v različnih načinih organizacije sporočila, mestu jedrnega zloga, neuporabi padajoče-rastočega tonskega poteka in predvsem v ožjem izkoristku glasovnega razpona.

Ključne besede: jezikoslovje, prozodija, kontrastivna analiza 


\section{Unenthusiastic Europeans or Affected English: the Impact of Intonation on the Overall Make-up of Speech}

\section{Introduction}

Speakers express their emotions and attitudes to the addressee(s) and the topic of interaction by means of linguistic as well as paralinguistic features. The linguistic features mainly encompass the choice of words and the syntactic structures, whereas the body language is the main paralinguistic feature. Intonation has both linguistic as well as paralinguistic features.

The linguistic function of intonation is expressed in linking grammar and spoken discourse. Intonation plays an important role in the organization and interpretation of the message. Its paralinguistic function is in providing additional meaning to what is supplied by the words themselves: it expresses emotions and attitudes to the addressee(s) and to the topic of conversation.

This article examines the prosodic features involved in the organization of the message and the transmission of attitudes and emotions in English. The features are tonality, tonicity, the pitch movement and the pitch range of tones. The article discusses the problems that non-native speakers of English may have in mastering the English prosody and the consequences that their prosodic inadequacies may have on the overall image of their speech.

\section{Tonality and tonicity in English}

Languages differ in the way their syntactic constraints allow them to organize information in a sentence or an utterance. In other words, some languages have very fixed rules regarding the word order, while others exhibit more flexibility in that respect. Languages with a very developed system of inflections, such as Slovene, allow for more variation in the order of sentence elements than English.

In order to organize and convey information to their addressees, speakers use two processes: they divide information into smaller chunks (i.e. intonation units) and within them choose one lexical item to bear the main prominence (i.e. nucleus). The former process is called tonality, the latter tonicity.

Tonality divides speech into intonation units where one unit contains one piece of information. What that piece of information is largely depends on the speaker's perception of the organization of information. This means that 'rules' for the division of speech into intonation units are to be understood as guidelines rather than hard and fast rules. 
Halliday (1967) observes that very often intonation units coincide with clauses and refers to such cases as neutral tonality. Cases where intonation units do not coincide with whole clauses are cases of marked tonality.

Tench (1996) recognizes two types of marked tonality: first, cases when two clauses are joined into one intonation unit, and second, when one clause is covered by two intonation units. Marked tonality of the latter type occurs in English in the following cases:

- $\quad$ the separation of the subject (i.e. the theme) from the predicate (i.e. the rheme) when the former is relatively long;

- $\quad$ a clause element precedes the subject of the clause and becomes the theme;

- $\quad$ some adjuncts;

- vocatives.

Apart from its function in the organization of information, tonality in English plays an important role in disambiguating certain syntactic structures, such as defining and nondefining items, apposition and complex verb phrases.

Every intonation unit has one obligatory syllable, the tonic syllable or the nucleus - this is the minimum. Many word groups have more than just one syllable. The tonic is acoustically the most prominent syllable in an intonation unit and as such also the carrier of the most important piece of information.

As with tonality, there is neutral and marked tonicity. Tench (ibid.) recognizes neutral tonicity when the tonic falls on the last lexical item in an intonation unit. When this is the case, the information of the whole intonation unit is in focus. In other words, everything is new information.

Marked tonicity is when the tonic falls on a non-final lexical item, when the final is old information, or when it falls on a grammatical word. With marked tonicity the information of only a part of an intonation unit is in focus, i.e. the part up to the tonic. Thus the focus is narrow. Contrast - lexical and grammatical - is probably the most frequent case of narrow focus.

The other important role of tonicity in English is to mark the syntactic contrast between:

- a reflexive and an emphatic pronoun,

- a vocative and a direct object to a transitive verb,

- a comment adjunct and an adjunct of manner.

\section{Tones and the pitch range}

Tones, pitch patterns and the pitch range play the most important role in conveying the speaker's attitude to the message or to the addressee(s). The attitude is conditioned by nonlinguistic elements (e.g. the context of situation) and expressed by paralinguistic (i.e. the body 
language) and linguistic features (i.e. intonation). The prosodic resources for the attitudinal meaning are the pitch level, the range of tones and different types of the pre-tonic segments and the pitch range of the whole pitch pattern.

Several renowned linguists have tried to describe the intonation system of English. The description of the American English intonation system was developed by Pike (1945), who was the first to have combined the tone range with the attitudinal meanings expressed by intonation. He developed a kind of tonal morphology whereby he tried to isolate meanings of the basic pitch levels and pitch movements. He used 4 pitch levels for the analysis of meanings of falls, rises, fall-rises and rise-falls when they begin and end on one particular pitch. Pitch level 1 corresponds to high, while pitch level 4 corresponds to low. Level 2 corresponds to mid-high and level 3 to mid-low. The attitudinal meanings vary according to the type of tone and the pitch range they cover. So for example, a fall from level 3 to level 4 sounds "mild" and "detached" and is used for "professional aloofness", while a fall from level 1 to 4 is "intense" and "unexpected" and is used to express "gushiness" (Pike, 1945).

In the British tradition authors such as Crystal (1975), O'Connor and Arnold (1975) and to some extent also Halliday $(1967,1970)$ tried to ascribe attitudes and meanings of different tones of the British English standard pronunciation, i.e. Received Pronunciation (RP).

Crystal (1975) concentrated mainly on the description of the pitch range and movement on the tonic syllable and ignored the pitch movement and range in the pre-tonic segments. His system recognizes 7 tones whose position in the sentence contributes to the attitudinal meanings.

Halliday $(1967,1970)$ tried to combine attitudinal meanings into one general intonation system, which also included information structure, syntactic contrasts and the communicative functions. Unlike Crystal, he included in his model the pre-tonic pitch movements (i.e. key) and came up with a list of 14 patterns.

O'Connor and Arnold's description of RP (1975) intonation distinguishes among 7 tones (of which the fall and the rise can be either high or low). In addition there are 4 pre-tonic pitch movements (i.e. heads): high, low, rising and falling, as well as two pre-heads (high and low). The combinations of pre-tonic pitch movements and tones are divided into 10 tunes with more or less transparent names. In addition they also recognize emphatic tunes which contain stepping, sliding or gliding heads. The ten tunes can be used in all sentence types, but their attitudinal meanings sometimes vary considerably.

The positive side of the model is that it provides attitudinal meanings for the whole tune and not separately for the tone and the pre-tonic segment. The problem, however, is that the attitudinal meanings are as diverse as the type of situation they can occur in. 


\section{Native English vs. European English}

It is a well-known fact that intonation varies considerably from one language to another. One need not be a trained musician to hear that the changes of the pitch movement in English are different from those of, for example, French, German, Spanish or Slovene. Comments like, "It wasn't so much what they said as the way they said it," show how strongly people react to intonation. Although native speakers are normally not consciously aware of intonation, they are nevertheless very sensitive to it - especially when it runs counter to their expectations. When they hear an unusual intonation, they usually do not take immediate offence but instead search for an implied meaning. If they cannot find it, they may be bewildered, and if the same intonation pattern persists, they may find it irritating. Very often native speakers of English find foreigners speaking English either rude and aggressive or flat, boring and uninterested in conversation.

\subsection{Experiment}

As a linguist and a teacher of English I was keen to find out the reasons for such unpleasant impressions that non-native speakers of English make on the native ones. Thus I decided to measure and analyse speech produced by 12 different European speakers of English. I chose the recordings of 11 European speakers reading the same short text in English. The recordings accompany the book by Michael Swan and Bernard Smith (2001) entitled Learner English. Since there is no recording of a Slovene speaker, I decided to record 10 Slovene learners of English reading the same text as the other speakers included in the study. I thereby obtained a small corpus of 21 recordings which contained the readings of non-native speakers of English from the Netherlands, France, Germany, Greece, Italy, Norway, Portugal, Poland, Russia, Slovenia (10 speakers), Spain and Turkey.

The analysis was both audio and instrumental. The instrumental analysis was used for the measurement of the pitch range of tones as well as the whole intonation units. The measuring units were semi-tones, which are equally suitable for male and female voices.

\subsection{Text}

The model text consisted of 25 intonation units. The tones were mainly falls (18) and fall-rises (7). The pitch range extended from high to low key.

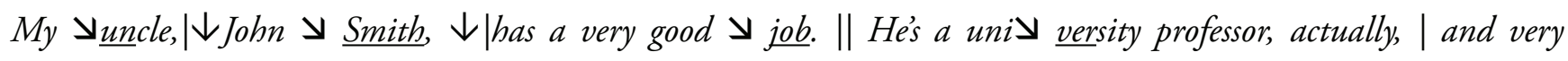

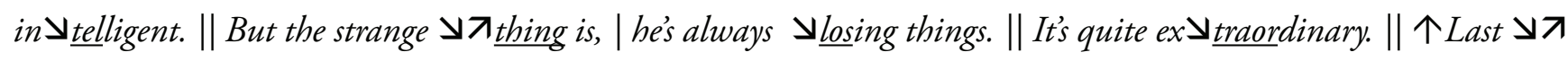
Thursday, for example, $\mid \downarrow$ during a trip to $\ \boldsymbol{\searrow}$ London on business, $\downarrow \mid$ he accidentally left his um $\searrow$ brella on the train. || It must be the sixth $\$ time he's lost that same umbrella. || It's a rather $\$ special one, | $\downarrow$ with red and yellow

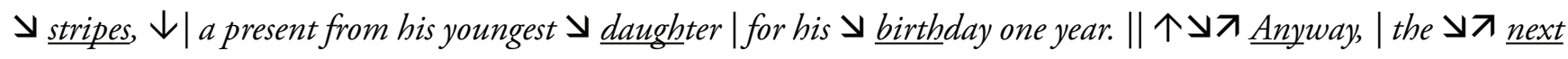
day, | as $\boldsymbol{У} \boldsymbol{\nearrow}$ soon as he was free, | he called at the Lost $\boldsymbol{\searrow}$ Property Office $\mid$ to $\$ ask about it. || in the next street to his $\downarrow$ house. $\|$ He's no $\$ stranger to the people there. $\| \downarrow$ They know him quite $\downarrow$ well. $\| \downarrow$ 
The analysis of the recordings focused on five parameters:

1) division into intonation units,

2) nucleus-placement,

3) pitch movement of nuclear and pre-nuclear segments,

4) pitch range of nuclear tones,

5) pitch range of intonation units.

\section{Results}

\subsection{Division into intonation units}

Most speakers observed the punctuation marks and divided the text into intonation units accordingly. Since in this text a large majority of intonation units did overlap with punctuation marks, this was generally not a problem. There are a few exceptions, however, which are considered to be wrong or inappropriate in the given context.

First, almost all speakers read actually and for example as separate intonation units thus assigning them full lexical meaning which they do not require in their contexts - the text would be perfectly grammatical and clear even without actually and for example.

Second, 17 of 21 (80.9\%) informants divided the sentence (1) into two word groups (1a)

(1) It must be the sixth time he's lost that same umbrella

(1a) It must be the sixth time | he's lost that same umbrella

which is wrong because it emphasises old information. The part of the sentence following sixth time conveys old information and as such should be unstressed. Treating it as a separate intonation unit means assigning it prominence to which this chunk of information is not entitled.

Third, 15 of $21(71.4 \%)$ informants read the intonation units $(2-4)$ as two units instead of one $(2 a-4 a)$.

(2) during a trip to London on business

(2a) during a trip to London | on business.

(3) a present from his youngest daughter

(3a) a present $\mid$ from his youngest daughter

(4) for his birthday one year

(4a) for his birthday | one year

These divisions are not as problematic as the one in (1a) since they do not express old information. Nevertheless, they are awkward since they either split a phrase (2a, 3a) or give emphasis to an adjunct (4a). All three cases produce unjustified marked information. 


\subsection{Nucleus placement}

Choosing the right lexical item to become the carrier of the most prominent syllable in the intonation unit did not cause many problems. However, the problems that did occur, occurred with 18 speakers (85.7\%). The errors could be divided into three groups.

First, there are cases where speakers stressed the wrong item in a compound. This happened in two compounds: university professor and Lost Property Office. In both cases the speakers decided to put the nucleus on the last word in the compounds instead of on the first and second, respectively:

(5) *university professor

(5a) university professor

(6) * Lost Property Office

(6a) Lost Property Office.

The second frequent mistake occurred with function words, which are by default unstressed and as such cannot carry the nucleus:

(7) * *trange thing $\underline{i s}$

(8) * rather special one

(9) * to ask about $\underline{i t}$.

The third most common occurrence of misplaced nucleus produced unjustified narrow focus. The nucleus did not occur on the last lexical item but was moved further to the left, giving the impression that all information following the nucleus was old:

(10) *it must be the sixth time

(11) *it's in the next street to his house

(12) *he's no stranger to the people there.

\subsection{Pitch movement of nuclear and pre-nuclear segments}

The analysis of the recordings has shown two patterns that seem to be typical of all non-native speakers of English and may indicate a general intonation pattern typically used in reading.

The first pattern refers to the pitch movement of the nuclear tone where all non-native speakers of English used simple rising intonation in non-final and falling intonation in final intonation units.

(13) My $\boldsymbol{\lambda u n c l e , | J o h n} \pi \underline{\text { Smith }}$ | has a very good $\mathbf{\searrow}$ job. 
In addition to that, the falling pitch contour continued even after the falling nuclear tone as in (14):

(14) It must be the sixth $\searrow$ time

he's lost

that same

umbrella.

The analysis of the use of tones has shown that all speakers used the falls and the rises. Only 3 speakers (French, Norwegian, Spanish) used also the fall-rise. It is difficult to find a plausible explanation for that. It may be that they have been taught to use it, or were exposed to native English speech a lot (the Norwegian speaker said that she had spent several months in the UK).

As stated above (cf. Section 3), the pitch movement of the pre-nuclear segment is another prosodic resource for attitudinal meanings. The analysis has shown two prevailing pitch movements in pre-nuclear segments.

The first one is gradually falling with no step up in pitch for the falling tone:

$$
\text { be acci den tal }{ }^{2}
$$

his um

\section{$\searrow \underline{\text { brella }}$}

on the

train.

It seems that this pitch movement is more natural and in agreement with the prevailing tendency of gradually descending pre-nuclear patterns. The problem is not so much in the descending pre-nuclear segment as in the lack of a pitch jump from a relatively low to a higher pitch. Low pitched falling tones are often interpreted as cool, dispassionate, reserved and dull (O'Connor and Arnold, 1973:48).

The other typical pre-nuclear pitch movement is gradually rising and followed by a high fall:

$$
\begin{array}{ll} 
& \multicolumn{1}{c}{\text { ydaugh }} \\
\text { youngest } & \text { ter. }
\end{array}
$$

a present 
The pitch movement of the whole intonation unit does indeed cover the whole pitch range, but its pre-nuclear crescendo (which is followed by a high falling tone) may be understood as protesting (O’Connor and Arnold, 1973:73).

\subsection{Pitch range of the nuclear tones and the whole intonation units}

The pitch range of nuclear tones and the whole intonation units plays a very important role in the transmission of attitudinal meanings. It is a common belief that in English falling tones with a narrow pitch range express dullness, sadness and the speaker's lack of interest in conversation. Wider pitch ranges of the falls, on the contrary, express just the opposite: liveliness, involvement in interaction and positive attitudes to the addressee(s).

The instrumental analysis has shown that the non-native speakers of English produced falling tones whose average pitch range did not exceed 5.1 semi-tones. The native speaker's falling tones reached 11.6 semi-tones which is almost one octave.

The average pitch range of whole intonation units and its variations among different nonnative speakers of English is best presented in the below table:

\begin{tabular}{|l|c|}
\hline Nationality & Average range in semitones (ST) \\
\hline Dutch (female) & 22 \\
\hline French (female) & 11 \\
\hline German (male) & 10 \\
\hline Greek (male) & 6 \\
\hline Italian (female) & 18 \\
\hline Norwegian (female) & 10 \\
\hline Polish (female) & 8 \\
\hline Portugese (male) & 6 \\
\hline Russian (female) & 8 \\
\hline Slovene (male and female) & 11 \\
\hline Spanish (male) & 7 \\
\hline Turkish (male) & 10 \\
\hline
\end{tabular}

The average pitch range of the intonation unit produced by a native speaker of English is around one octave. 


\section{Conclusion}

When native speakers of English listen to foreigners speaking English, they very often claim that non-native speakers sound dull, uninterested in conversation, rude or even aggressive. It has been established that there are a few prosodic features on the basis of which the attitudinal meanings are expressed and perceived. The most important seem to be the type of pitch movements and their range. The audio and instrumental analyses of spoken English produced by 21 Europeans have shown certain general traits of English spoken by foreigners.

Firstly, the organization of the message into intonation units is usually unproblematic, a claim that cannot be made for the nucleus placement. The main problem are function words which are in English stressed only in cases of marked tonicity. In many other languages, however, the function words can be made more or less prominent.

Secondly, the reason for dull and boring speech lies in the rhythm. There are two features common to all foreign speakers: all words are equally prominent (i.e. no distinction is made between weak and strong forms of function words) and all the statements have the same pattern (rises in non-final intonation units and falls in the final ones).

Thirdly, the pitch movements on the nuclei are falling and rising. The fall-rise, which is the second most frequent tone in English, was used only by three speakers.

And finally, the pitch contours of the whole tunes are gradually descending. There is no step up in pitch after the falling pre-nuclear segment and the falling tone. Instead, the fall begins at the same pitch height where the pre-nuclear segment has finished. In addition the pitch range of both, the tones and the whole intonation units, is relatively narrow (i.e. > 12 semi-tones).

Among other reasons for sounding flat and uninterested it is important to mention that most foreign speakers rely too much on punctuation, read words instead of meaningful units and exhibit certain fear and uneasiness using a foreign language.

\section{Bibliography}

Crystal, D. 1975. The English Tone of Voice. London: Edward Arnold.

Halliday, M.A.K. 1967. Intonation and Grammar in British English. The Hague: Mouton.

Halliday, M.A.K. 1970. A Course in Spoken English: Intonation. London: Oxford University Press.

O'Connor, J.D., and G.F: Arnold. 1973, 2nd. Intonation of Colloquial English. London: Longman.

Pike, K.L. 1945. The Intonation of American English. Ann Arbor: University of Michigan Press.

Swan, M., and B. Smith, eds. 2001, 2nd. Learner English: A Teacher's Guide to Interference and Other Problems. Cambridge: Cambridge University Press.

Tench, P. 1996. The Intonation Systems of English. London:Cassell.

Toporišič, J. 1984, 2nd. Slovenska slovnica. Maribor: Založba Obzorja. 